\title{
BENEFITS AND CHALLENGES OF PASTORALISM SYSTEM IN ETHIOPIA
}

\author{
Abdulkadr Ahmed Abduletif \\ PhD Student \\ Enyedi György Doctoral School of Regional Sciences, Faculty of Economics and Social \\ Sciences, Szent István University \\ E-mail: Ahmed.Abdulkadr@phd.uni-szie.hu
}

\begin{abstract}
Pastoralism is an important livelihood system practice in most of the dryland areas of the globe. It is a source of income and way of livelihood for hundreds of millions of world population. This research aimed at explaining the benefits of pastoral system, identifying the main challenges the sector faced based on secondary data obtained from different official records such as FAO, CSA (Central Statistical Authority of Ethiopia) and published research article and government reports. Besides this, this research also tried to indicate the possible way outs. Economically it contributes about $10 \%-40 \%$ of national GDP of countries and over 1.3 billion people benefited from the livestock value chain. Ethiopia has the largest livestock population in Africa (first in Africa, and 5th in the world) and $20 \%$ of the national export and $90 \%$ of live animal export of the Ethiopian trade, and $80 \%$ of annual milk supply to the Ethiopian community resulted directly from the pastoralists. Yet the sectorial contribution has many bottlenecks and the most important one is lack of appropriate policy due to the misconception that the system is economically not feasible and environmentally unfriendly. In addition to this, unexpected, but short period drought and weak market chain, limited access to feed, equipment and information, market chain, animal health (veterinary) are contributing factors to the low contribution of the livestock sector. Ethiopia, with its huge livestock population and the increasing demand of global meat and milk demand, should give attention towards the sectorial development including provision of infrastructure such as milk and milk processing industries, leather and leather processing industries, and focus on Diversification of economic activities in the pastoral areas. Besides, the government of Ethiopia should give an emphasis on developing policies and strategies to increase productivity of livestock and maintain the development of the sector. Furthermore, the government should devise mechanisms to control the illegal interboarder live animal export and way of measuring unaccounted (nonmarketable) values of livestock pastoral contributions.
\end{abstract}

Keywords: Pastoralism, Livestock, Sustainability, Challenges,

JEL classification: $F 63,013$

LCC: $S 589.75-589.76$, HT388

\section{Introduction to Ethiopian Pastoral System}

Pastoralism is one of the main livelihoods in the world's drylands through livestock production. According to league to pastoral people and endogenous livestock development, Pastoralists are those who primarily use livestock production as a means of living in a dry area with high temperature, shortage of rainfall and lack of access to grazing lands.

Production and livelihood are the most common and widely used perspectives to define pastoralism. In the production perspective, pastoralism is defined as branch of agriculture concerned with livestock production in dry or cold rangeland areas, whereas in the livelihood perspective, it's a way of living with herds of animals Blench (2001), or a way of leading life 
on less productive lands via livestock herding (IFAD, 2008) and delivers huge economic and environmental contributions. Pastoralism to Ethiopian pastoral community is a means of livelihood system though the government of Ethiopia defines as part of agricultural production.

Pastoral system (an alternative term for pastoralism) is a mechanism found in rangeland areas with a relatively large size of animals characterized by the use of livestock grazing. The main aim of management of livestock in a pastoral system is to maintain, minimize risk and adapt to institutional environments with a proper use of communal grazing area. This indicates that the system is highly integrated to increasing its livestock productivity in the shared grazing land. Besides pastoralists are responsible to maintain the ecosystem so as to get enough grasses to feed their livestock.

According to UNEP (2014), pastoralism is exercised by more than 200 million people across the world including nomads, transhumant herders, and agro-pastoral communities producing high quality of livestock products (milk, meat, fiber, and leather etc.) Under the same report, it is stated that the system has a mechanism of conserving the rangeland biodiversity and protecting ecosystem on more than one-fourth of the world's rangeland pastoralists occupy.

Most of the researches that have been done on pastoralism are categorized in the area of anthropology, natural science, and environments. In this regard, Anthropologists took the highest credit in qualitatively identifying the social integrity of the pastoral community and their livestock. On the other hand, the issue of livestock raising and range management was the main concern of Natural scientists and agronomists on their study of pastoralism. Whereas environmentalists, mainly involved in the studies with the concern for risky ecological conditions of the pastoralists and their emphasis was in the area of natural resources and the dangers that might be involved by the community which disregards the holistic approach (Konsczacki Z. A .1978).

(Blench, 2001) indicated that mobility of pastoralists often used as a key factor to classify types of pastoralism. Pastoralists in Ethiopia can be categorized as nomadic and transhumant. Nomadic pastoralism is a way of living with no fixed seasonal location whereas transhumant pastoralism is a mobile system where the pastoralists rotate the same areas across different seasons. There are also other forms of pastoralism such as pastoral farming (pastoral mobility with little or no long-distance movement).

In addition, there is agro-pastoralism in the transition zone between pastoral areas and agricultural areas. People who live on agro-pastoralism are called "agro-pastoralists. Agropastoralism is defined as a set of practices that combines pastoral livelihoods with a production of millet, sorghum, maize, vegetables, and pulses (annual legumes). By definition, the difference between pastoralism and agro-pastoralism is that the main income generating mechanism pastoralists is livestock and livestock products, whereas cultivation with the small number of livestock production is the main source of income for agro-pastoralists (IFAD, 2008).

The prospective of agriculture are challenged by efficiency problems in many African and other developing countries, like in Nigeria, where half of the arable land of the country is not cultivated while considerable food import is needed to supply the population. Modern and largescale farms are not common there as well (Neszmélyi, 2016), Besides Nigeria and a significant part of Ethiopia the scarcity of water can be considered as another factor that limit the efficiency of farming and it can generate international tensions, like among riparian countries on the distribution of the runoff of Nile river (Kozár-Neszmélyi, 2019). In other developing 
economies, like in the newly industrializing Asian economies (South-Korea, Taiwan), the overall lack of arable lands and the scattered, miniature sized farms (Neszmélyi, 2017) are the limiting constraints.

According to FAO (2015), Ethiopia has the largest livestock population in Africa (first in Africa, and 5th in the world). CSA (2017) data showed that there are 59.486 million heads of cattle, 30.69 million sheep, 30.2 million goats, 59.49 million all poultry (Chicken, laying hens, non-laying hens, pullets, cockerels, cocks), 11 million equines (donkeys, horses, mules) and 1.2 million camels, and 6.18 million beehives distributed in all the administrative regions. Cattle are a very common asset in Ethiopian households; 12.5 million households, or 70 percent of the total population, depend fully or partly on cattle for their livelihoods (FAO, 2018).

Although $20 \%$ of the national export and $90 \%$ of live animal export of the Ethiopian trade, and $80 \%$ of annual milk supply to the Ethiopian community resulted directly from the pastoralists. Yet the sectorial contribution is low. Therefore, the main aim of this research is to explain the benefits of pastoral system, identify the main challenges the sector has been facing. Besides, this research will also to indicate the possible way outs.

\section{Material and Methods}

Pastoralism as a system has long been considered as the mainstay of the rural society living in dryland areas in such a way that majority of the community has relied on it. Besides the pastoral areas identified by the government, the livestock population size in the remaining regions is much higher. This indicates that, almost all rural Ethiopian community is involved in livestock production and one way another all Ethiopians depend on it. This study designed to assess the hypothesis that livestock sector and the pastoral system has more advantage than its disadvantages implicated by several environmentalists. In this research, secondary data obtained from different official records such as FAO, CSA (Central Statistical Authority of Ethiopia) and published research article and government reports were used to answer the research hypothesis.

\section{Results}

\section{Benefits of Pastoral System}

Ethiopia is one of the developing countries blessed with an immense, but untapped livestock resources scattered over diverse agro-ecologies. About $12 \%$ of Ethiopia's 74 million people are pastoralists (CSA, 2008), herding their livestock in the arid and semi-arid lowlands that constitute about $63 \%$ of the country's land mass (MoARD, 2008).

As indicated on the figl above, the total cattle population in the year $2017 / 18$ has increased by 6.41 million while sheep population has increased by 5.8 million and goat by about 8.6 million in the given period. As it can be seen from the chart, majority of the animals are female sex and almost all are indigenous types. In general, we can understand that the livestock population of cattle, sheep and goats has an increasing trend over the study period.

Pastoralism has a significant contribution to countries national GDP (10\%-44\%) and over 1.3 billion people are estimated benefiting from livestock value chain (WISP 2016). According to Coalition of European Lobbies on Eastern African Pastoralism (CELEP) report (CELEP, 2017), $20 \%$ of the national export and $90 \%$ of live animal export of the Ethiopian trade, and $80 \%$ of annual milk supply to the Ethiopian community resulted directly from the pastoralists and 
contributes 19\%, 13\% and 8\% of GDP in Ethiopia, Kenya and Uganda, respectively (Nyariki, 2017). It also contributes close to $60 \%$ of the meat and milk products consumed in West African countries (United Nations Economic Commission for Africa (UNECA, 2016).

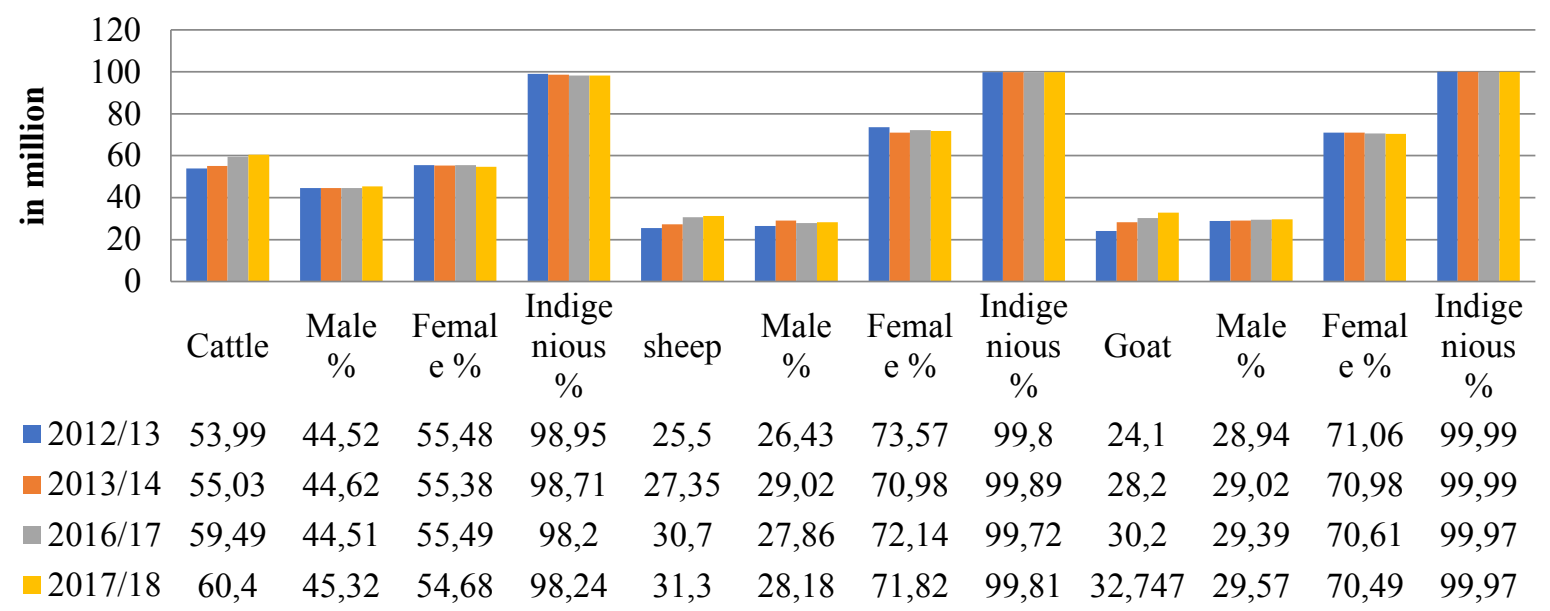

Fig 1: Estimated cattle, sheep and goat population by sex, and breed Ethiopia from 2012/13-2017/18

\section{Source: Central Statistical Authority of Ethiopia, 2018}

Pastoralism has a significant contribution to countries national GDP (10\%-44\%) and over 1.3 billion people are estimated benefiting from livestock value chain (WISP 2016). According to Coalition of European Lobbies on Eastern African Pastoralism (CELEP) report (CELEP, 2017), $20 \%$ of the national export and $90 \%$ of live animal export of the Ethiopian trade, and $80 \%$ of annual milk supply to the Ethiopian community resulted directly from the pastoralists and contributes 19\%, 13\% and 8\% of GDP in Ethiopia, Kenya and Uganda, respectively (Nyariki, 2017). It also contributes close to $60 \%$ of the meat and milk products consumed in West African countries (United Nations Economic Commission for Africa (UNECA, 2016).

Pastoralism plays a pivotal role in the national economy by providing labor income, food, nutrition security for the pastoral community. Besides, it is the best system to use marginalized and less productive lands. It also helps sustain and preserve the natural resources and the ecosystem (Mohammed Yimer (2015), brief for GSDR. Furthermore, it is the best way for communities living in a very harsh environment with high temperature, low amount of rainfall and water sources. According to report by Catley and Andy (2017) in Feinstein International Center and Mohammed Yimer (2015) in a Brief for GSDR, pastoralism is the best alternative than agriculture in rangelands where rainfall is very limited and other sources of long-lasting water source are scarce.

The decrease in livestock population will lead pastoralists to search for other options of income generation like destroying trees to produce charcoal which will negatively impact the rangeland ecology (Riginos et al. 2012). It is, therefore, better to develop policies which will enhance the livestock productivity as high-income pastoralists gain, they will be responsible to protect the rangeland ecology (Hausner et al. 2012). A review conducted by (Tessema, et.al., 2014) concluded that pastoral system is sustainable and gives a suggestion that its sustainability will depend on mobility, adaptation and on pastoral institutions.

As even nowadays livestock plays an important role in the lives of the entire population. $90 \%$ of employment opportunities and $95 \%$ of the family income and nutritional security in arid and 
semi-arid land of Kenya derived from pastoralism (CELEP, 2017), and has not lost its economic, political and social relevance to Afar people. (D. Tsegaye et al., 2013). Results of the household survey of (FAO 2018) show that livestock activities are major contributors to livelihoods through income and nutrition-related benefits, with cattle and cattle products playing a significant role. These results are an underestimation because non-marketable livestock outputs, such as draft power, manure, social bride have not been accounted for. According to (Nyariki and Ngugi, 2002), livestock also play a pivotal role in socio-cultural purposes as sources of reputation, wealth, and dowry. They also underestimate the potential benefits livestock can generate if current productivity gaps due to lack of access to inputs, technology, information, and basic services were addressed - only 50 percent of the holding have at least one cattle vaccinated, and 66 percent reported to have access to veterinary services.

\section{Challenges Of pastoral system}

Having huge number of livestock population, the pastoral community in Ethiopia have been facing multiple challenges in their day to day life due to natural factors which need to be resolved through appropriate strategies. Pastoralis as a system has long been affected by many factors such as political, socio-economic and cultural marginalization, poor access to infrastructure and services, unpredicted climate changes (Jenet, A. et al., 2016). According to Cousins et al., (2007) the lives, choices and decisions of pastoralists were challenged by the vibrant social, economic and ecological causes.

One of the key challenges the pastoralists facing relates to the rooted misconception that pastoralism is not economically feasible and environmentally unfriendly way of livelihood which led government authorities to inspire pastoralists to settle. Though pastoralism plays a prominent role in the livelihood of inhabitants, their contribution to the economy has been ignored by national policies and focused at modernizing them by introducing to the agriculture which is assumed to be the best way to ensure development and avoid or minimize poverty (Mohammed 2010). For example, in Ethiopia the contribution of livestock production to the agriculture was $47 \%$ in 2009 though this figure was underestimated by the nation, and this underestimation was resulted due to unofficial exports around the inter boarder trades (IGAD, 2013). In addition to this, low level of technological adaptation, lack of entrepreneurial skills and weak knowledge dissemination contributed a lot to the low productivity of the livestock sector.

Agricultural Development Led Industrialization (ADLI), which was developed as Ethiopia's development policy in 1995, focuses on modernizing small-scale agriculture holders and intensifying yield productivity through the supply of appropriate technology, certified seeds, fertilizers, rural credit facilities and technical assistance to alleviate poverty. In other words, the policy implementation emphasizes the transformation of pastoralists to semi pastoralist, and agrarian then to transform the whole economic system into industrialization which marginalizes the community's social and cultural values towards their herds and ignores the importance of pastoralism as an economic system. This is indicated by Zewdie B.B. (2015) that adequate attention to the pastoral community is not given in the ADLI policy. Besides, IGAD (2013) in its policy brief series implied the presence of extensive policy bias against livestock production and marketing by undermining the contribution. This can be strengthened with the research findings of James et al., (2014) stating that development in pastoral area of Ethiopia is considered as backward system and marginalized for very long period.

The unexpected, but short period drought and weak market chain forced pastoralists to look for some other sources of income like charcoal production besides their livestock production so as 
to continue their livelihood (Devereux 2006). Such conditions increased the influences of ecologists and politicians on pastoralists (Abule et al. 2005) and put the system under question mark.

With the increasing sedentarization of pastoralists, the reduction in labor input in mobile livestock rearing may lead to a shift from multiple pastoralism toward solely pastoral farming or agro-pastoralism production, implying a terrible loss of diversity of pastoralism. As a result, the practices of pastoralism have been overwhelmed. If these situations continue, it is likely that pastoral societies across the world will have more unpleasant fates in the future (S. Dong et al. (eds.) 2016). Even though sedentarization of pastoralists have a positive impact when it comes to getting better access to education, healthcare and water sources, the social values of the pastoral community will be lost as a result of decrement to their livestock size to cope up with the environment. Based on the researchers experience, nomadic/transhumant way of life is better to get better nutrition than those who settled even though those who settled ones have an advantage over the nomads in getting access to education and healthcare facilities which contradicts to the policy aims in alleviating poverty. In addition to this, as the size of livestock decreases, the contribution of the sector to the economy will be minimized and even with the recurrent climate changes where the decrement in rainfall amount the community will not be able to feed themselves well. Besides, the decrease of livestock production will lead pastoralists to produce charcoal as a means on income generating option which will negatively affect the environment. In addition to this, (UNEP, 2014) stated that the research findings of the last twenty years disclaim the argument that pastoralism is backward, providing that it is not only economically very important but also preserves the ecosystem.

For several years, development policies towards pastoralism shared the view that the increase in livestock population as a reason for desertification and the traditional social and economic systems (especially communal land tenure) forced them not to apply technologies to protect the desertification. The environmentalists and some groups such as green peace target industrial countries often blame the poor rural producer for their unsound practices to protect earth's natural resources against further degradation and propose strategies to remove the indigenous people to save habitats. (Leach and Mearns, 1996). The idea of the environmentalists is not, of course, bad when we come to protecting the ecology. The problem is that the importance of livestock production is not observed well with regard to their contribution in maintaining the ecosystem. Live animals provide very powerful nonmarketable outputs which mostly are not taken seriously like manure and well-preserved rangelands have a great role for carbon sinks. The pastoral communities are very much keen in protecting their environment with their traditional conservation mechanisms. The problem with some of the development plans in the past, for example in the 1960s-1980s like sweeping privatization of land and commercialization of livestock production, was the view that agronomists and development planners had towards Hardin tragedy of commons (Herdin 1968:1244). This view was that the increase in African livestock productivity to feed its growing demand (McMichael et al 2007) by minimizing the size of herds on rangelands rather than improving livestock productivity (Simpson and Evangelou, 1984). According to (Mohammed 2004, 2010) the failure for development agencies which have been working with Ethiopian pastoral community (for example in Afar) resulted due to the ignorance of the local knowledge of the community.

The tragedy of responsibility associated with modernizing traditional pastoral practices and preserving modernist worldviews (Kreutzmann, 2013) by replacing sedentary agriculture (Solomon and Abebe 2014; James et al. 2014) is currently challenging the sustainable development of pastoralism. Modernizing the pastoral system is very important. 
The other reason for the low contribution of livestock sector to the Ethiopian economy is not is lack of quality of products. One of the main constraints is the source of feed. The following are some of the contributing constraints to sources of feed.

Feed quality and quantity: natural grazing is the main sources of feed which doesn't constitute the required nutritional contents that livestock need to meet the quality that the market demands. Besides, in Ethiopian highlands the grazing land has been decreasing due to the growing demand for agricultural land as a result of rapid population growth.

The other contributor is the ecological deterioration. Nowadays pastoralism became very difficult sector to deal with especially in lowlands due to the ecological mismanagement. Land tenure/change of ownership is another contributor as national and regional land use policy allows regions to decide and use a certain grazing area for investment on the communally owned and traditionally managed grazing areas. The investors once they got the area might even prevent or limit the free movement of nomads and their livestock. In addition to the above constraints, the recurrent drought and unpredicted minimal amount of rainfall has contributed to soil degradation due to overgrazing which in turn increase the vulnerability of the pastoral community.

\section{Possible way out}

When it comes to sustainability for pastoralists, it is a means of living in a way that it is their power to keep their livestock and its productivity, their resources, and assurance of political security and their economy. Their sustainability is determined by their practice on livestock mobility. Pastoral societies are proud of their system which is a main livelihood system for a very long period.

According to recent Food and Agriculture Organization (FAO) projections, the demand for meat will increase by $80 \%$ by 2030 and by more than $200 \%$ by 2050 in lower- and middleincome countries (FAO, 2018). Such high demand is projected due to the high rate of population growth (Hassen et al., 2016; UN, 2017). Majority of the livestock products are obtained from smallholders (FAO, 2015, IFAD, 2015). Besides, the demand for livestock products such as milk, meat, and eggs are growing rapidly in Ethiopia (Thornoton, 2010; Wright et al., 2012).

To meet the projected demands, it is necessary to focus on increasing productivity of livestock and maintain the development of the sector. In this regard, the limitations of smallholders such as access to feed, equipment and information, market chain, animal health (veterinary) should be in place. In addition to this, low level of technological adaptation, lack of entrepreneurial skills and weak knowledge dissemination contributed a lot to the low productivity of the livestock sector. This can be done without replacing the system by other systems like sedentary agriculture. This modernization of pastoral system can be achieved by introducing technologies such as leather and leather products' industry, Milk and milk products' processing industry, meat production and processing industries to the communities.

According to D. Tsegaye et al., (2013), the annual household income for pastoralists is lower than semi-pastoralists and agro-pastoralists and this indicates the combining livestock production and dryland farming would enhance or maintain the livelihood of the households. This means that agro-pastoralists are likely to have better living standards than pastoralists and semi-pastoralists. However, agro-pastoralists have the challenge of relying on good weather which is never reliable especially around pastoral rangelands. This makes pastoralists better be placed to survive in dry regions as the shift from pastoralism to non-pastoral way of life will be 
difficult for those pastoralists who used to it. Though several development platforms inspire agro-pastoralism, sustainability of pastoral development requires livestock mobility (B. G. J. S. Sonneveld et al 2017) with proper infrastructure and appropriate policies enabling pastoralists to get an access to social services ( Niamir-Fuller 2000)

In a study conducted by (Galvin 2009, B. Worku 2016) reported that a typical strategy for rural livelihood is diversification of economic activities. Some of the Ethiopia pastoral community adopted new strategies in response to environmental changes, altered market, and everchanging political conditions, but without total detachment from traditional mobile herding regimes (D. Tsegaye et al., 2013).

D. Tsegaye et al., (2013), recommended that the pastoral system shouldn't be ignored from the economic system even though sedentarization has increased. Rather, the responsible authority should develop appropriate policies which can enhance productivity. For better pastoral livelihood, the development planners and policymakers should give attention to the old way of livestock keeping strategy and create a strong market chain. Besides, pastoralists should have the right to pasture and water, rights guaranteed by law (communal, village-based or cooperative tenure) and veterinary access. Moreover, as indicated in S. Dong et al. (eds.) (2016), Pastoralism will be kept as the backbone of the economy and as the mainstay of ecosystem protection in marginal and fragile areas, because it is generally regarded as an efficient, low-energy-requiring subsistence base for these areas.

In addition to these, the government should recognize the customary resource management. Megersa et al. (2014) and Abdulatife M, Ebro A (2015) stated that pastoralists have acquired a wealth of traditional knowledge of maintaining their livelihood and the environment they surround. Besides, the responsible authorities should work towards strengthening of the use of the traditional knowledge (Angassa et al. 2012, Abate, 2016) with the modern knowledge (Tilahun et al. 2016, Eva Kaye-Zwiebel and Elizabeth King 2014) through continuous awareness creation trainings (Olaotswe Kgosikoma 2012, Abdulatife M, and Ebro A 2015) as it plays an important role in maintaining rangeland resources and in the advancement of scientific research and achieving the development goals (Feye 2007; Mohammed 2004, 2010; Angassa et al. 2012; Sulieman and Ahmed 2013).

\section{Conclusions}

Pastoralism is one of the livelihood mechanisms for hundreds of millions of people in the world. The system is also a direct source of income of almost 12 percent of the population of the second most populous country in Africa. Its contribution to the national economy is very significant although the underestimation of the sector is seen over the years including in the new homegrown economic reforms proposed by the premier's office on September 2019. The system has long been challenged by several factors. Politically, the policy makers attention is towards transforming the system to agrarian system rather than implementing and enhancing infrastructure that might contribute to the development of the livestock sector. The rooted misconception that pastoralism is a backward and environmentally Unfriendly system is another obstacle to the development of the sector. Ethiopia, with its huge livestock population and the increasing demand of global meat and milk demand, should give attention towards the sectorial development including provision of infrastructure such as milk and milk processing industries, leather and leather processing industries etc. Diversification of economic activities can contribute the maximization of rangeland production. Enhancing pastoral institutions and providing services and infrastructures which will fit the nomadic and transhumant lifestyle of the pastoralists will help pastoral system to contribute better than what it has been contributing. 
Above all, the government of Ethiopia should give an emphasis on developing policies and strategies to increase productivity of livestock and maintain the development of the sector. In this regard, the limitations of smallholders should be solved. Besides the government should devise mechanisms to control the illegal inter-boarder live animal export and way of measuring unaccounted (nonmarketable) values of livestock pastoral contributions.

\section{References}

1. Abate, T. (2016). Indigenous Ecological Knowledge And Pastoralist Perception On Rangeland Management And Degradation In Guji Zone Of South Ethiopia. The Journal Of Sustainable Development, 15(1), 192-218.

2. Abdulatife M, Ebro A (2015). Assessment Of Pastoral Perceptions Towards Range And Livestock Management Practices In Chifra District Of Afar Regional State, Ethiopia. Forest Res 4: 144. Doi:10.4172/2168-9776.1000144

3. Abule E, Snyman Ha, Smit Gn (2005) Comparisons Of Pastoralists Perceptions About Rangeland Resource Utilization In The Middle Awash Valley Of Ethiopia. J Environ Manage. Vol 75: p. 21-35. doi: 10.1016/j.jenvman.2004.11.003

4. Angassa A, Oba G, Stenseth Nc (2012) Community-Based Knowledge Of Indigenous Vegetation In Arid African Landscapes. The Journal Of Sustainable Development Vol. 8, No 1. P:70-85

5. B. Worku, N. L. (2016). Pastoral Perceptions Towards Livestock And Rangeland Management Practices In Kuraz District Of South Omo Zone, South Western Ethiopia. Journal Of Natural Sciences Research. Vol.6, No.1., P. 60-69. ISSN 2224-3186

6. Blench R (2001) You Can’t Go Home Again: Pastoralism In The New Millennium. Overseas Development Institute, London

7. Catley, Andy. Pathways to Resilience in Pastoralist Areas: A Synthesis of Research in the Horn of Africa. Boston: Feinstein International Center, Tufts University, 2017.

8. CELEP (2017, May). Celep Policy Brief: Recognising The Role And Value Of Pastoralism And Pastoralists. Retrieved October 05, 2018, From Celep: Http://Www.Celep.Info/Wp-Content/Uploads/2017/05/Policybrief-Celep-May-2017Value-Of-Pastoralism.Pdf

9. Cousins B, Hoffman Mt, Allsopp N, Rohde Rf (2007) A Synthesis Of Sociological And Biological Perspectives On Sustainable Land Use In Namaqualand. J Arid Environ 70:834-846. Doi:10.1016/J. Jaridenv.2007.04.002

10. CSA (Central Statistical Authority) (2008). Summary And Statistical Report Of The 2007. Population And Housing Census. Addis Ababa, Ethiopia.

11. CSA. (2017). Agricultural Sample Survey, Livestock And Livestock Characteristics ( Private Peasant Holdings). Addis Ababa, Ethiopia: Central Statistical Agency Of Federal Democratic Republic Of Ethiopia.

12. D. Tsegaye, P. V. (2013). Pastoralism And Livelihood: A Case Study From Northern Afar, Ethiopia. Journal Of Arid Environments, Vol. 91, p 138-146. doi:10.1016/j.jaridenv.2013.01.002

13. Devereux S (2006). Vulnerable Livelihoods In Somali Region. Ids Research Report, Ethiopia, 57

14. FAO (2015), World Cattle Inventory: Ranking Of Countries, Web Site, Https://Www.Drovers.Com/Article/World-Cattle-Inventory-Ranking-Countries-Fao, Accessed November 6/2018

15. FAO, IFAD, UNICEF, WFP and WHO. 2018. The State of Food Security and Nutrition in the World 2018. Building climate resilience for food security and nutrition. Rome, FAO. Licence: CC BY-NC-SA 3.0 IGO. 
16. Feye Y (2007) Pastoralists Perception Towards Range Resource Utilization And Range Condition Assessment In Gewane District Of Afar Regional State, Ethiopia. Msc Thesis. School Of Graduate Studies, Haramaya University. p 65-66

17. Galvin Ka (2009) Transitions: Pastoralists Living With Change. Annu Rev Anthropol Vol. 38:185-198. Doi:10.1146/Annurev-Anthro-091908-164442

18. Hardin G (1968). The Tragedy Of The Commons. Science 162:1243-1248

19. Hassen, I.W., Dereje, M., Minten, B., Hirvonen, K., 2016. Diet transformation in Africa: the caseof Ethiopia. Ethiopia Strategy Support Program. IFPRI. Vol. 48, p.7386. DOI: 10.1111 /agec.12387

20. Hausner Vh, Fauchald P, Jernsletten J (2012). Community-Based Management: Under What Conditions Do Sa'mi Pastoralists Manage Pastures Sustainably? Plos One Vol. 7 No. 12. Doi:10.1371/Journal. Pone.0051187

21. IFAD. (2008). Annual Report . Ifadifad. (2008). Annual Report, Enabling Poor Rural People To Overcome Poverty. Ifad.

22. IFAD, 2015. Smallholder Livestock Develop: Scaling Up Note. International Fund for Agricultural Development, Rome, Italy.

23. IGAD, (2013). The Contribution Of Livestock To The Ethiopian Economy, Policy Brief. Retrieved October 06, 2018, From Igad Center For Pastoral Areas \& Livestock Development (Icpald).

24. James K, Michago Ws, Eid A, Admasu Lk (2014) Large Scale Land Deals In Ethiopia: Scale, Trends, Features And Outcomes To Date. Idrc And Iied, London, P 62. ISSN: 2225-739X, ISBN: 978-1-78431-020-2

25. James R. Simpson and Phylo Evangelou, Livestock Development in Subsaharan Africa: constraints, prospects, policy. Westview Replica Editions. Boulder, Col.: Westview Press, 1984, 408 pp

26. Jenet, A., N. Buono, S. Di Lello, M. Gomarasca, C. Heine, S. Mason, M. Nori, R. Saavedra, K. Van Troos. 2016. The Path To Greener Pastures. Pastoralism, The Backbone Of The World's Drylands. Vétérinaires Sans Frontières International (VsfInternational). Brussels, Belgium.

27. Kaye-Zwiebel, E., \& King, E. (2014). Kenyan Pastoralist Societies In Transition: Varying Perceptions Of The Value Of Ecosystem Services. Ecology And Society, 19(3). doi.:10.5751/ES-06753-190317.

28. Konczacki, Z. A. (1978). The Economics Of Pastoralism: A Case Study Of SubSaharan Africa . Taylor And Francis. ISBN 0-7146-3086-1

29. Kozár L.- Neszmélyi Gy (2014): Water Crisis in the Nile-Basin -: Is It Really a Zero Sum Game?

30. Journal of American Business Review, Cambridge $2: 2$ pp. 91-98 (2014)

31. Kreutzmann, H. (2013). The Tragedy Of Resposibility In High Asia: Modernising Traditional Pastoral Practices And Preserving Modernist Worldviews. Pastoralism: Research, Policy And Practice. Vol. 3 No. 7. doi:10.1186/2041-7136-3-7

32. McMichael, A. J., Powles, J. W., Butler, C. D., \& Uauy, R. (2007). Food, Livestock Production, Energy, Climate Change, And Health. The Lacent. Vol 370: No. 9594 p. 1253-1263. DOI:10.1016/S0140-6736(07)61256-2

33. Megersa B, Andre M, Angassa A, Anne Vz (2014) The Role Of Livestock Diversification In Ensuring Household Food Security Under A Changing Climate In Borana, Ethiopia. Journal Of Food Science Vol 6 No.1, p:15-28. Doi:10.1007/s12571013-0314-4

34. Melissa Leach and Robin Mearns 1996. In, Melissa Leach \& Robin Mearns (eds). The Lie of the Land: Challenging Received Wisdom on the African Environment. Oxford: James Currey, DOI: 10.2307/3557002 
35. MOARD (Ministry Of Agriculture And Rural Development) (2008). Relief Interventions In Pastoralist Areas Of Ethiopia. Addis Ababa.

36. Mohammed Y (2004) Pastoral And Land Tenure Issues And Development In The Middle Of Awash Valley. Msc Thesis. Addis Ababa University, Addis Ababa, Ethiopia, $130 \mathrm{P}$

37. Mohammed Y (2010). Is It A Silent Travel To Death? Case Of The Subaltran Children Of Lucy. Uppsala, Sweden

38. Mohammed Yimer (2015) Brief For Gsdr Pastoral Development Pathways In Ethiopia; The Policy Environment And Critical Constraints

39. Neszmélyi Gy. (2016): Társadalmi és gazdasági kihívások Nigériában (Social and economic challenges in Nigeria)

40. Földrajzi Közlemények $140: 2$ pp. 107-123.

41. Neszmélyi, Gy. (2017): The Challenges of Economic and Agricultural Developments of Taiwan: Comparison with South Korea. Tribun EU s.r.o. Brno, 2017151 p. ISBN: 9788026313311

42. Niamir-Fuller. (2000). Managing Mobility in African Rangelands. Retrieved December 1, 2018, from Research gate: https://www.researchgate.net/publication/237218321_Managing_Mobility_in_Africa n_Rangelands

43. Nyariki, D.M. 2017. Assessment of the economic valuation of pastoralism in Kenya. A report for IGAD, Nairobi, Kenya.

44. Nyariki, D.M., and R.K. Ngugi. 2002. A review of African pastoral production system: Approaches to their understanding and development. Journal of Human Ecology. Vol.13 No.3, p. 137-250. doi: 10.1080/09709274.2002.11905539

45. Olaotswe Kgosikoma, 2012, Witness Mojeremane, Barbra A. Harvie, Ecology And Society, Vol. 17, No. 4, Resilience Alliance Inc

46. Riginos C, Porensky L, Veblen K Et Al (2012) Lessons On The Relationship Between Livestock Husbandry And Biodiversity From The Kenya Long-Term Exclosure Experiment. Pastoralism: Res, Policy Prac 2:10. Doi:10.1186/2041-7136-2-10

47. S. Dong Et Al. (Eds.), (2016). Building Resilience Of Human-Natural Systems Of Pastoralism In The Developing World: Interdisciplinary Perspectives, Doi 10.1007/978-3-319-3072-9 1

48. Solomon B, Abebe M (2014) Safeguarding Pastoral Land Use Rights In Ethiopia. Conference On Land Policy In Africa., 11-14 November, 2014, Addis Ababa

49. Sonneveld, B., Van Wesenbeeck, C., Keyzer, M., Beyene, F., Georgis, K., Urbano, F., Meroni, M., Et Al. (2017). Identifying Hot Spots Of Critical Forage Supply In Dryland Nomadic Pastoralist Areas: A Case Study For The Afar Region, Ethiopia. Land, 6(4), 82. Mdpi Ag. doi:10.3390/land6040082

50. Sulieman H, Ahmed A (2013) Monitoring Changes In Pastoral Resources In Eastern Sudan: A Synthesis Of Remote Sensing And Local Knowledge. Vol 3 No. 22

51. Tessema, W.K., Ingenbleek, P.T.M. \& Van Trijp, H.C.M. (2014). Pastoralism, sustainability, and marketing. A review. Agron. Sustain. Dev. Vol 34: p.75-92. doi: 10.1007/S13593-013-0167-4

52. Thornton, P.K., (2010). Livestock production: recent trends, future prospects. Philos. Trans. R. Soc. B. Vol 365, p.2853-2867. doi:10.1098/rstb.2010.0134

53. Tilahun, M., Angassa, A., Abebe, A., \& Mengistu, A. (2016). Perception And Attitude Of Pastoralists On The Use And Conservation Of Rangeland Resources In Afar Region, Ethiopia. Ecological Process. Vol 5 No. 18. DOI 10.1186/s13717-016-00624 
54. UN (2017). World Population Prospects: The 2017 Revision, Key Findings and Advance Tables. United Nations, Department of Economic and Social Affairs, Population Division, New York, USA.

55. UNECA (United Nations Economic Commission for Africa). 2016. Expert group meeting on New Fringe Pastoralism (NFP) development, conflict and insecurity in the Horn of Africa and the Sahel. 25-27 Aug 2016. http://databank.worldbank.org/data/databases.aspx/.

56. UNEP. (2014, May 21). Sustainable Pastoralism And The Post 2015 Agenda. Retrieved Novomeber 10, 2018, From Unep: Https://Sustainabledevelopment.Un.Org/Content/Documents/3777unep.Pdf

57. WISP, W. I. (2016, August 09). Pastoralism To Sustaining Rangelands Ecology. Retrieved October 07, 2018, From World Initiative For Sustainable Pastoralism, Wisp: Http://Www.Fao.Org/3/A-Bq715e.Pdf

58. Wright, LA., Tarawali, S., Blummel, M., Gerard, B., Teufel, N., Herrero, M., (2012). Integrating Crop and livestock in Subtropical Agricultural System. J.Scie. Food Agric. Vol. 92, p.1010-1015. DOI 10.1002/jsfa.4556

59. Zewdie, B. B. (2015). Analyses Of Agricultural Development Led Industrialization (ADLI) Policy's Effectiveness In Ethiopia. Journal for Studies In ManagementAnd Planning, vol. 01 No. 11. 